\title{
Study on Carbon Emission Efficiency of China's Industrial Industry and Analysis of Its Influencing Factors
}

\author{
Jie Yi \\ Jinan University, Guangzhou, China \\ Email: 852549371@qq.com
}

How to cite this paper: Yi, J. (2017) Study on Carbon Emission Efficiency of China's Industrial Industry and Analysis of Its Influencing Factors. Low Carbon Economy, 8, 20-30.

https://doi.org/10.4236/lce.2017.81002

Received: March 8, 2017

Accepted: March 26, 2017

Published: March 31, 2017

Copyright $\odot 2017$ by author and Scientific Research Publishing Inc. This work is licensed under the Creative Commons Attribution International License (CC BY 4.0).

http://creativecommons.org/licenses/by/4.0/ (c) (i) Open Access

\begin{abstract}
Based on the careful calculation of the carbon dioxide emissions from 1996 to 2014 in China's industrial sector, the efficiency of all-element carbon emissions in 35 industrial sectors was measured by the super-efficiency DEA method. Finally, this paper uses the Tobit model to explore the main factors that cause the change of carbon emission efficiency, and grasp the influence direction and influence degree of these factors on the carbon emission efficiency, and put forward some suggestions for these influencing factors. Through the study, this article found that carbon emissions of China's industrial sector grew rapidly, but in recent years has become convergence. The overall level of carbon efficiency in the industrial sector is low and there is a large emission reduction. Those industries with high degree of openness, adequate funding for $R \& D$, and a certain scale have a higher carbon efficiency.
\end{abstract}

\section{Keywords}

Industrial Carbon Emissions, Industry Carbon Emissions Efficiency, Super Efficiency DEA

\section{Introduction}

From the industrial revolution, especially in the last 20 years, the greenhouse effect continues to increase, triggering a series of environmental crises, such as accelerating global warming, causing the Arctic ice to continue to melt resulting in sea level rise and so on. The data released by the WRI (World Resources Institute) show that greenhouse gas emissions from human activities have reached 46 billion metric tons in 2010, up 35 percent from 1990 levels. During the past 20 years, major greenhouse gas emissions have continued to increase: Nitrogen oxide emissions increased by $9 \%$, methane gas emissions increased by $15 \%$, and 
carbon dioxide emissions increased by $42 \%$. As carbon dioxide emissions account for about 3/4 of the total GHG emissions, its emissions increase enough to affect the overall emissions of greenhouse gases. The sharp rise in greenhouse gas concentrations is the rise in global average temperatures. IPCC (United Nations Intergovernmental Panel on Climate Change) published a climate report shows that from 1880 to 2012, the world average temperature has risen by 0.85 degrees Celsius. The report warned that if the human society does not take effective action in time, then by the end of the twenty-first century, the world's average temperature may rise up to 4.8 degrees Celsius, causing great damage to human society.

In order to cope with the climate and climate problems caused by greenhouse gases such as carbon dioxide, governments around the world and the corresponding international organizations have carried out a series of activities to control and reduce greenhouse gas emissions, and the Chinese government is actively involved. As a big industrial country, the total amount of carbon dioxide emissions in China is large and growing rapidly. As early as 2006, the total amount of carbon dioxide emissions exceeded the United States; in 2013 the total amount of carbon dioxide emissions is more than 10 billion tons, beyond the United States and the EU countries and the first time in per capita carbon dioxide emissions beyond the EU countries.

As a responsible world power, the Chinese government to the United Nations Framework Convention on Climate Change submitted to the secretariat of China's response to climate change national self-contribution document "to strengthen climate change action-China's national contribution", commitment to reduce carbon emissions per unit of GDP by $40 \%$ - $45 \%$ in 2020; in 2030, carbon emissions per unit of GDP are 60\% - 65\% lower than in 2005 and in 2030 or so to reach the peak carbon emissions. Achieving these goals is a major challenge for China, to achieve sustained economic development and control of carbon dioxide emissions, requiring the government must pay attention to enhance the efficiency of carbon dioxide emissions.

The industrial sector is the main sector of China's carbon dioxide emissions, and its emissions account for more than $70 \%$ of the total carbon dioxide. Studying the issue of carbon dioxide emissions and emission efficiency in the industrial sector, analyzing the trends and influencing factors behind it will help to understand the current situation of China's current carbon dioxide emissions and then formulate a series of policies without affecting the development of industrial economy while controlling carbon dioxide emissions, to achieve sustainable economic development.

\section{Literature Review}

With the deepening of research on carbon dioxide emissions in recent years, there have been various evaluation indexes and calculation models for various angles, different ranges and different periods.

Kaya et al. (1993) first proposed the concept of "carbon production efficiency" 
to measure the proportion of GDP produced by a subject in a period of time and the amount of carbon dioxide produced in the production process to measure economic growth while pursuing economic growth [1]. To the extent of the impact. Mielnik, Goldemberg (1999) pioneered the concept of "carbon index" to assess the economic development model and environmental protection of developing countries by using the indicator of the amount of carbon dioxide emitted per unit of standard energy [2].

The carbon productivity, carbon intensity and carbon index and other single factor indicators are intuitive and easy to use, in the early literature has been widely studied and applied. Unlike the single factor carbon efficiency indicators, the elements of the whole factor not only focus on the relationship between output and carbon dioxide, but also take into account the substitution of various factors of production, the labor, capital stock and other factors of production into carbon dioxide Emission efficiency analysis.

Färe et al. (1989) incorporated the negative effects of the environment as undesired outputs into the traditional DEA model [3]. The efficiency measure of this environmental impact embodies the idea of the all-factor model and promotes the DEA model in environmental efficiency analysis Applications. Hailu and Veeman (2001) used the DEA method to measure and analyze the relative $\mathrm{CO} 2$ emissions efficiency of Canadian papermaking industry, depending on the unwanted output of carbon dioxide emissions in the production process [4]. Ramanathan (2006) used the DEA method to analyze the relationship between energy consumption, carbon emissions and GDP output in the world's major powers [5]. Mandil (2007) measures the carbon emissions from manufacturing and measures to improve energy efficiency and carbon efficiency by measuring the total carbon emissions and emissions efficiency of the manufacturing sector [6]. Kortelainen (2008) constructed the EPI environmental performance index of 20 countries in the 1990-2003 EU to study the efficiency of its carbon emissions by combining the frontier analysis technique and the Malmquist index [7]. Zhou $\mathrm{P}$ et al. (2010) based on the Malmquist index, measured the carbon emissions performance of the world's 18 major carbon dioxide emissions and explored the main influencing factors that led to changes in carbon emissions efficiency [8].

In addition, some studies are also analyzed from the perspective of the marginal cost of carbon dioxide emissions, such as Maradan and Vassiliev (2005) [9], Marklund and Samakovlis (2007) [10] using different DEA models, respectively, including 76 developed and developing countries, the carbon dioxide margin Cost of emission reduction.

Chinese scholars also have a certain amount of research on carbon emissions and carbon efficiency. Hu Angang et al. (2008) incorporated carbon dioxide emissions into the total factor productivity model expressed by the directional distance function to measure the productivity performance of China's provinces [11]. Chen Shiyi (2009) put carbon emissions into the input variables, using the logarithmic production function to calculate the total factor productivity of China's industrial sub-sectors and calculate the green growth-related data, that 
capital and energy is an important factor driving industrial growth, While the role of carbon emissions growth is relatively weak [12]. Xi Jianguo (2013) used carbon emissions as an input factor, using the DEA model to measure the carbon efficiency of each province, and further to the provinces of carbon emissions efficiency to do a convergence analysis and found that only the eastern region of the carbon efficiency of the province is Convergent [13]. Wu Xianrong (2014) used the DEA-Malmquist index two-stage method to measure the agricultural carbon emission efficiency of 31 provinces, and further analyzed the changes in carbon efficiency of the provinces and the driving factors, found that the provinces and cities of agricultural carbon emissions efficiency was significant Differences, and technological progress is the main driver of carbon efficiency improvements [14].

From the above domestic and foreign research literature we can see that for the study of carbon emissions in China, most of the research is to select the region as a research object, and less to industry perspective to study carbon emissions efficiency. And the study of the industry's carbon efficiency differences, especially high energy consumption and high emissions of carbon emissions efficiency and trends, is a certain research value.

\section{Industrial Carbon Emissions Calculation}

In the current carbon emissions study, some of the literature only considers three major primary energy sources-coal, crude oil, natural gas, carbon dioxide emissions, while ignoring other secondary energy sources of carbon dioxide emissions and indirect emissions.

Therefore, this article will be based on the United Nations Intergovernmental Panel on Climate Change (IPCC) designated "National Greenhouse Gas Inventories Guide" energy provided by the reference method, combined with China more in line with the actual situation of the "provincial greenhouse gas inventory preparation guidelines." The formula is as follows:

$$
C_{t}=\sum_{i=1}^{n} C_{i, t}=\sum_{i=1}^{n} E_{i, t} \times N C V_{i} \times C E F_{i} \times C O F_{i} \times(44 / 12)
$$

Where $\mathrm{C}$ represents the estimated amount of carbon dioxide emissions and $\mathrm{i}$ represents the type of energy. NCV is the average calorific value of energy, CEF represents the energy of the carbon emission factor. COF represents the oxidation factor.

The results of each calculation are shown in Table 1.

Based on the calculation of various types of fossil energy emission factors, this paper estimates the energy consumption of various types of fossil fuels based on the energy balance table in China Energy Yearbook and China Statistical Yearbook, and estimated the industrial energy consumption from 1996 to 2014 Industry carbon dioxide emissions data, basically reflects the status of China's industrial carbon dioxide emissions [15]. The results are shown in Table 2 (the table is made by EXCEL software).

Overall, the industrial sector's carbon dioxide emissions increased from 
Table 1. Energy Emission Coefficient.

\begin{tabular}{ccccc}
\hline Type & $\begin{array}{c}\text { Oxidation } \\
\text { rate }\end{array}$ & $\begin{array}{c}\text { Carbon } \\
\text { content }\end{array}$ & $\begin{array}{c}\text { Calorific } \\
\text { value }\end{array}$ & $\begin{array}{c}\text { Emission } \\
\text { factor }\end{array}$ \\
\hline raw coal & 0.93 & 26.37 & 20908 & 1.880 \\
Wash the clean coal & 0.93 & 25.41 & 26344 & 2.283 \\
Other coal washing & 0.93 & 25.41 & 9760 & 0.846 \\
Coke & 0.93 & 29.42 & 28435 & 2.853 \\
Coke oven gas & 0.99 & 13.58 & 17353 & 0.855 \\
Blast furnace gas & 0.99 & 70.8 & 3211 & 0.825 \\
Converter gas & 0.99 & 49.6 & 9531 & 1.716 \\
Other gas & 0.99 & 61.75 & 4475 & 1.003 \\
Other coking products & 0.93 & 29.5 & 38098 & 3.832 \\
crude & 0.98 & 20.08 & 41816 & 3.017 \\
gasoline & 0.98 & 18.9 & 43070 & 2.925 \\
kerosene & 0.98 & 19.6 & 43070 & 3.033 \\
Diesel & 0.98 & 20.2 & 42652 & 3.096 \\
Fuel oil & 0.98 & 21.1 & 41816 & 3.170 \\
liquefied petroleum gas & 0.98 & 17.2 & 50179 & 3.101 \\
Refinery dry gas & 0.98 & 18.2 & 45998 & 3.008 \\
Other petroleum products & 0.98 & 20 & 35167 & 2.527 \\
natural gas & 0.99 & 15.32 & 38931 & 2.165 \\
liquefied natural gas & 0.99 & 17.2 & 48000 & 2.997 \\
\hline
\end{tabular}

207.56 million tons in 1996 to 655.89 million tons in 2014, the total growth of $216 \%$, the average annual growth rate of $6.6 \%$. China's industrial sector, the difference between the growth rate of carbon dioxide emissions can be broadly divided into five stages. The first phase is from 1996 to 2001, carbon dioxide emissions increased from 2.06 billion tons to 2.19 billion tons, 5 years, a total increase of only $6.25 \%$; this may be affected by the financial crisis in Asia, and then superimposed on China's state-owned enterprise restructuring In the past few years reached a climax, a large number of enterprises shut down the impact. The second phase of 2002 to 2007, carbon dioxide emissions increased from 2.19 billion tons to 4.28 billion tons, the average annual growth rate of up to $11.9 \%, 6$ years a total increase of $95.9 \%$, nearly doubled; at this stage, China's new world Trade organizations, exports soared, to promote the rapid growth of the industrial sector. The third stage is from 2008 to 2010 , the three-year growth rate was $3.43 \%, 4.89 \%, 4.30 \%$, industrial industry, carbon dioxide emissions growth rate decreased significantly; at this time began in the United States global financial crisis is outbreak, China as an export Big country, by the impact of considerable. After 2011, industrial carbon emissions growth again higher, 2011-2013 average growth of $11.4 \%$; this stage, including China gradually out of the financial crisis, the economy began to rebound. Finally, the total carbon emissions in China's industrial sector fell slightly by $1.69 \%$ in 2014 , and according to the International Energy Agency's report, China's total carbon emissions fell by 1.5\% in 2015; this change is due to the rise in China's clean energy Faster. 
Table 2. Carbon dioxide emissions from China's industrial sector.

\begin{tabular}{|c|c|c|c|c|c|c|c|c|}
\hline Industry & 1996 & 1999 & 2002 & 2005 & 2008 & 2011 & 2014 & $\begin{array}{l}\text { Average } \\
\text { growth rate }\end{array}$ \\
\hline Coal mining and washing industry & 8528 & 8759 & 9433 & 15076 & 17415 & 19525 & 17400 & $4.04 \%$ \\
\hline Oil and gas extraction industry & 4858 & 6246 & 7502 & 6902 & 7852 & 7155 & 7603 & $2.52 \%$ \\
\hline Black metal mining industry & 838 & 809 & 1044 & 2280 & 3242 & 4495 & 5015 & $10.45 \%$ \\
\hline Non-ferrous metal mining industry & 1505 & 851 & 1068 & 1574 & 1954 & 2674 & 2815 & $3.54 \%$ \\
\hline Non-metallic mining industry & 1287 & 1346 & 1652 & 2030 & 2197 & 2539 & 2951 & $4.72 \%$ \\
\hline Agricultural processing industry & 4146 & 3745 & 4082 & 4577 & 5645 & 6268 & 8703 & $4.21 \%$ \\
\hline Food manufacturing industry & 2487 & 2530 & 2483 & 2570 & 3046 & 3246 & 3960 & $2.62 \%$ \\
\hline Beverage manufacturing & 2086 & 2036 & 1951 & 2180 & 2414 & 2582 & 3621 & $3.11 \%$ \\
\hline Tobacco products industry & 562 & 793 & 711 & 570 & 499 & 617 & 483 & $-0.83 \%$ \\
\hline Textile industry & 6982 & 6240 & 7257 & 10699 & 12437 & 13155 & 13346 & $3.66 \%$ \\
\hline garment footwear manufacturing industry & 692 & 798 & 903 & 1266 & 1572 & 1722 & 2001 & $6.08 \%$ \\
\hline Leather and its products industry & 410 & 491 & 540 & 727 & 853 & 843 & 1336 & $6.78 \%$ \\
\hline Wood processing and products industry & 809 & 830 & 867 & 1718 & 2200 & 2584 & 2992 & $7.54 \%$ \\
\hline Furniture manufacturing industry & 382 & 239 & 225 & 298 & 396 & 454 & 748 & $3.80 \%$ \\
\hline Paper and paper products industry & 4627 & 4541 & 5614 & 7310 & 8039 & 8465 & 7838 & $2.97 \%$ \\
\hline Printing and recording media & 451 & 426 & 487 & 629 & 755 & 880 & 971 & $4.35 \%$ \\
\hline $\begin{array}{l}\text { Cultural and educational sporting goods } \\
\text { manufacturing industry }\end{array}$ & 191 & 249 & 377 & 449 & 489 & 535 & 837 & $8.57 \%$ \\
\hline $\begin{array}{l}\text { Oil processing, coking and nuclear fuel } \\
\text { processing industry }\end{array}$ & 5501 & 11527 & 13961 & 18844 & 21072 & 23451 & 28615 & $9.59 \%$ \\
\hline $\begin{array}{l}\text { Chemical raw materials and chemical products } \\
\text { manufacturing industry }\end{array}$ & 42471 & 28726 & 33640 & 48067 & 59262 & 64556 & 89125 & $4.20 \%$ \\
\hline Chemical fiber manufacturing industry & 1946 & 3165 & 3687 & 2670 & 2756 & 3018 & 3449 & $3.23 \%$ \\
\hline Rubber and plastic products industry & 2893 & 2969 & 3371 & 5904 & 7084 & 8125 & 9443 & $6.79 \%$ \\
\hline Non-metallic mineral products industry & 31119 & 33137 & 30341 & 48827 & 57786 & 72548 & 88841 & $6.00 \%$ \\
\hline $\begin{array}{l}\text { Ferrous metal smelting and rolling processing } \\
\text { industry }\end{array}$ & 45035 & 46126 & 51964 & 103649 & 135425 & 169209 & 235413 & $9.62 \%$ \\
\hline $\begin{array}{l}\text { Non-ferrous metal smelting and } \\
\text { rolling processing industry }\end{array}$ & 6941 & 8230 & 10059 & 16396 & 24722 & 31627 & 37051 & $9.75 \%$ \\
\hline Metal products industry & 2623 & 2677 & 3671 & 5218 & 6801 & 8142 & 10304 & $7.90 \%$ \\
\hline General equipment manufacturing industry & 4122 & 3094 & 3403 & 5127 & 6427 & 9313 & 8249 & $3.93 \%$ \\
\hline Special equipment manufacturing industry & 2240 & 2011 & 1920 & 2942 & 3614 & 4264 & 4255 & $3.63 \%$ \\
\hline $\begin{array}{l}\text { Transportation equipment manufacturing } \\
\text { industry }\end{array}$ & 3076 & 3256 & 3902 & 4441 & 5918 & 8932 & 8351 & $5.70 \%$ \\
\hline $\begin{array}{l}\text { Electrical machinery and equipment } \\
\text { manufacturing industry }\end{array}$ & 1380 & 1422 & 1738 & 2678 & 3879 & 5068 & 5177 & $7.62 \%$ \\
\hline $\begin{array}{l}\text { Communications equipment, } \\
\text { computerelectronics manufacturing industry }\end{array}$ & 749 & 1343 & 1810 & 3240 & 4780 & 5937 & 6210 & $12.47 \%$ \\
\hline $\begin{array}{l}\text { Instrumentation and culture, office } \\
\text { machinery manufacturing industry }\end{array}$ & 349 & 343 & 404 & 438 & 624 & 720 & 630 & $3.33 \%$ \\
\hline $\begin{array}{l}\text { Electricity, heat production and supply } \\
\text { industry }\end{array}$ & 12348 & 15397 & 17963 & 22553 & 25477 & 33060 & 29837 & $5.02 \%$ \\
\hline Gas production and supply & 679 & 1009 & 967 & 943 & 1069 & 972 & 1281 & $3.59 \%$ \\
\hline Water production and supply & 1157 & 1324 & 1257 & 1591 & 1871 & 2390 & 2570 & $4.53 \%$ \\
\hline
\end{tabular}




\section{Industrial Sector Carbon Efficiency}

DEA (Data Envelopment Analysis) is a kind of systematic analysis method in the cross field of multidisciplinary disciplines such as econometrics, management, mathematics and operations research. It will be a unit of each evaluation as a decision-making unit, the decision-making unit can be either an enterprise can also be an economic system. These decision units must have the same kind of inputs and outputs. The DEA model determines the efficiency envelope based on the input-output values of these decision-making units and uses this as a benchmark to calculate the relative efficiency values for each decision-making unit.

When the relative efficiency of the decision unit is analyzed by the traditional DEA method, multiple units may be valid at the same time, that is, the relative efficiency value is 1 , and the traditional DEA model cannot make further comparisons. 1993 Andersen \& Perterson proposed ultra-efficient DEA model, these efficiency values can be 1 for the next unit of comparative analysis, to make up for the DEA model of this defect. The super-efficient DEA model is:

$$
\left\{\begin{array}{l}
\operatorname{Min} \theta, \\
\sum_{j=1, j \neq j_{0}}^{n} X_{\mathrm{j}} \lambda_{j}+s^{-}=\theta X_{0} \\
\sum_{j=1, j \neq j_{0}}^{n} Y_{\mathrm{j}} \lambda_{j}-s^{+}=Y_{0} \\
\lambda_{j} \geq 0 \\
s^{+} \geq 0, s^{-} \geq 0 \\
j=1,2, \cdots n
\end{array}\right.
$$

The super-efficient DEA model differs from the traditional model in that the decision-making units to be evaluated in the traditional model are included in all decision-making units, and the super-efficient DEA model excludes the decision-making units to be evaluated from the set of decision, At this time to evaluate the efficiency of the decision-making unit frontier will not contain the decision-making unit itself. This model will only be affected if the decision unit is active, and the effective unit will get an efficiency value greater than 1 .

In this paper, the industrial industry of carbon dioxide emissions, capital stock, the amount of labor as the input to the industry's total output as output, to build ultra-efficient DEA model, according to calculate the whole industry from 1996 to 2014 Elemental carbon emissions efficiency. The total output of the industrial sector and the labor force data from the "China Statistical Yearbook". Capital stock data are estimated using the PIM (perpetual inventory method), and the data used for the estimate comes from the China Industrial Yearbook [16] [17].

Through the use of ultra-efficient DEA, this paper calculates the total factor carbon efficiency of the whole industry from 1996 to 2014. Overall, the total factor carbon efficiency of all 35 industrial sectors at the end of the year (2014) is higher than that at the beginning of the year (1996), and the geometric mean of the total element carbon emissions in all industrial sectors increased from 0.173 
in 1996 to 20140.563 .

This suggests that there is a significant improvement in carbon efficiency as a whole in the industrial sector. The carbon efficiency of the industrial sector has a clear trend of improvement from 1996 to 2006; and in the four years from 2007 to 2010, the overall TFP efficiency of the industrial sector began to have a slight downward trend, Part of the industrial sector during this period of discharge efficiency and even a clear retrogression. After 2011, the overall efficiency of the industrial sector began to rise, but the magnitude has been greatly reduced. This is in line with China's industrial economic development trends, enterprise production efficiency and energy structure changes in line with the situation. During the period from 1996 to 2007, China's industry continued to change from a market economy, and the efficiency of carbon emissions was improved significantly. And 2007 to 2010 is a period of global financial crisis for a period of time, the export of industrial economy has been seriously affected, and then part of the industrial sector production efficiency and total factor carbon emissions efficiency of a slight decline. As the world gradually out of the shadow of the financial crisis, China's industrial industry as a whole carbon dioxide emissions continue to be small.

\section{Tobit Regression Analysis}

For least unilateral data, the least squares method is used for regression analysis, but when the data is truncated, the use of least squares regression may produce biased results. In order to solve this problem, the economist Tobin in the study of durable consumer demand, the first proposed a restricted dependent variable regression model, the Tobit model. The model uses the maximum likelihood estimation method to estimate the parameters of the variables.

Assuming that the explanatory variable is $\mathrm{y}_{\mathrm{i}}$, the minimum value of the explanatory variable is $y_{0}$, $\mathrm{xi}$ is the explanatory variable, and the linear regression model is constructed as follows:

$$
\begin{aligned}
& y_{i}=\left\{\begin{array}{l}
y_{t}^{*}, y_{t}^{*}>0 \\
0, y_{t}^{*} \leq 0
\end{array}\right. \\
& y_{t}^{*}=\beta^{T} x_{i}+e_{i}, e_{i} \sim N\left(0, \sigma^{2}\right)
\end{aligned}
$$

If $y_{t}^{*}>$, then $y_{i}=y_{t}^{*}$, where $y_{i}$ is an unrestricted observation, can be taken directly to the actual observations; if $y_{t}^{*} \leq 0$, then $y_{i}=0$, At this time is the limited observation.

Draw lessons from the relevant research results, and then the characteristics of China's industrial economy during the transition period, this paper mainly selected the following several external environmental factors to discuss the variables.

Technological progress, this paper selects the proportion of R \& D input and output in the industrial sector to measure technological progress.

Industry concentration, this paper uses the industrial sector in the output of large and medium-sized enterprises and the proportion of total output to the 
industry that the degree of concentration.

Property rights structure reform, this paper chooses the total output of various industrial sectors and the ratio of the number of enterprises in the industry to represent the size of enterprises in various industries.

Finally, the following basic econometric models are used to analyze the potential factors that affect the carbon efficiency of the industrial sector:

$$
E E_{i, t}=\beta_{0}+\beta_{1} \text { Soe }_{i, t}+\beta_{2} \text { Constra }_{i, t}+\beta_{3} R D_{i, t}+\beta_{4} \text { Scal }_{i, t}+\varepsilon_{i}
$$

where $\mathrm{EE}_{\mathrm{i}, \mathrm{t}}$ represents the carbon efficiency of China' various industrial sectors, $\mathrm{Soe}_{\mathrm{i}, \mathrm{t}}$ on behalf of the industry changes in the depth of property rights structure, Constra $a_{i, t}$ represents the degree of industrial concentration; $\mathrm{RD}_{\mathrm{i}, \mathrm{t}}$ to measure the technological progress of various industrial sectors; $\mathrm{Scal}_{\mathrm{i}, \mathrm{t}}$ represents the average size of the industry.

The results of the Tobit regression analysis of the carbon efficiency and influencing factors of China' industrial sub-sectors from 1996 to 2014 are shown in the table. The table shows how the carbon efficiency of the industrial sector is influenced by the structure of the property rights, industry concentration, technological progress and the average size of the firms in the industry. The specific analysis is as follows:

The coefficient of property rights index is -0.970 , indicating that the increase in the proportion of state-owned enterprises in the industrial sector will reduce the efficiency of carbon dioxide emissions in the industry. The output efficiency of state-owned enterprises is reduced by $0.97 \%$ on average for each $1 \%$ increase. Industry concentration is about positive for the carbon efficiency of the industrial sector, with a $1 \%$ increase in concentration and an average increase of $0.486 \%$ in carbon efficiency. Technological progress on China's industrial sector carbon emissions efficiency has a greater positive impact, the coefficient is estimated at 1.499, which shows that China's industrial $\mathrm{R} \& \mathrm{D}$ expenditure in the proportion of total output for each 1 percentage point increase, its total factor carbon emissions efficiency The average net increase of 1.499 percentage points. The average size of the firms in the industry has a positive impact on carbon efficiency and the results are tested by significance. This means that the input of carbon emissions in the industrial sector, like capital, labor and other factors, has the characteristics of scale returns, reducing the carbon dioxide emissions in the production process and improving the efficiency of emissions.

\section{Conclusion and Revelation}

Based on the detailed calculation of carbon dioxide emissions from industrial sub-sectors, this paper uses the ultra-efficient DEA method to measure the efficiency of total carbon in China's industrial sector from 1996 to 2014. The final establishment of the Tobit Metrological Model explores several factors that affect the carbon efficiency of the industrial sector. The main conclusions are as follows:

First, the growth of carbon dioxide emissions in China's industry in the past 19 years has grown rapidly from 2.08 billion tons at the beginning of the year to 
6.56 billion tons, up by 216 percent; the compound growth rate reached 6.6 percent, protecting the environment and reducing the pressure on carbon emissions. At the same time, the total amount of industrial carbon emissions in recent years has had some slowdown in 2014 and even a slight decline; this is partly due to the rapid increase in clean power generation, significantly reducing the average emission factor for electricity, reducing the industry for carbon dioxide emissions. The use of ultra-efficient DEA analysis of the industry's total factor carbon efficiency and its changing trends found that China's industrial sector carbon emissions efficiency has been significantly improved, but in 20072008, the overall efficiency of emissions decreased slightly, and 2008 after years, the rate of carbon efficiency in the industrial sector has slowed down. Tobit's return to industrial sector emissions panel data reveals that emissions from industries with a higher proportion of state-owned economies are less efficient and industry-based reforms are more efficient. The average size of the industrial sector has a positive impact on the efficiency of carbon emissions, carbon emission factors exist scale income characteristics. R \& D expenditure and the proportion of output on the carbon emission efficiency have a greater relevance, the higher the proportion of the industry, the emission efficiency tends to be higher.

In this paper, considering the use of indirect emissions caused by electricity, the calculation of carbon dioxide emissions from the industrial sector from 1996 to 2014, more realistic response to the industry's real carbon emissions. It is the basis for other studies to accurately assess the carbon efficiency of Chinese industry. Carbon emissions efficiency to lay the foundation. Then, the efficiency of carbon emission efficiency of each industry was estimated by using the super efficiency DEA, and several possible influencing factors were analyzed, which enriched the research on the carbon efficiency of China

For developing countries, it is important to reduce carbon emissions and develop the economy. In order to achieve the coordinated development of the two, we must study the emission efficiency of carbon dioxide. Studying the differences in carbon efficiency between China's industrial sectors and the reasons for the differences will help the government to develop appropriate industry policies to improve China's overall carbon efficiency and achieve the Chinese government's commitment to reducing emissions.

It should be pointed out that the trend of carbon emission efficiency in China's industrial industry is only a qualitative description of the analysis, cannot accurately reflect the trend of change; if the figures can accurately reflect the trend of change, will be more practical significance. In addition, limited to the availability of data, this paper analyzes the differences in carbon efficiency between industries, and if we can explore more factors, we can better analyze the differences between industries and improve the efficiency of carbon emissions.

\section{References}

[1] Kaya, Y. and Yokobori, K. (1993) Global Environment, Energy, and Economic Development Held at the United Nations University. Tokyo.. 
[2] Mielnik, O. and Goldemberg, J. (1999) Communication The Evolution of the "Carbonization Index" in Developing Countries. Energy Policy, 27, 307-308.

[3] Färe, R., Grosskopf, S., Lovell, C.A.K. and Pasurka, C. (1989) Multilateral Productivity Comparisons When Some Outputs Are Undesirable: A Nonparametric Approach. The Review of Economics and Statistics, 71, 90-98. https://doi.org/10.2307/1928055

[4] Hailu, A. (2003) Nonparametric Productivity Analysis with Undesirable Outputs: Reply. American Journal of Agricultural Economics, 85, 1075-1077. https://doi.org/10.1111/1467-8276.00511

[5] Ramanathan, R. (2006) A Multi-Factor Efficiency Perspective to the Relationships among World GDP, Energy Consumption and Carbon Dioxide Emissions. Technological Forecasting \& Social Change, 73, 483-494.

[6] Mandil, C. (2007) Tracking Industrial Energy Efficiency and $\mathrm{CO}_{2}$ Emissions. International Energy Agency, Paris, 45-68.

[7] Kortelainen, M. (2008) Dynamic Environmental Performance Analysis: A Malmquist Index Approach. Ecological Economics, 64, 701-715.

[8] Zhou, P., Ang, B.W. and Han, J.Y. (2010) Total Factor Carbon Emission Performance: A Malmquist Index Analysis. Energy Economics, 32, 194-201.

[9] Maradan, D. and Vassiliev, A. (2005) Marginal Costs of Carbon Dioxide Abatement: Empirical Evidence from Cross-Country Analysis. Swiss Journal of Economics \& Statistics, 141, 377-410.

[10] Marklund, P.O. and Samakovlis, E. (2007) What Is Driving the EU Burden-Sharing Agreement: Efficiency or Equity? Journal of Environmental Management, 85, 317-329.

[11] Hu, A., Zheng, J., Gao, Y., et al. (2008) Ranking of Provincial Technical Efficiency (1999-2005) Taking into Account Environmental Factors. Economics: Quarterly, No. 3, 933-960.

[12] Chen, S. (2009) Energy Consumption, Carbon Dioxide Emissions and Sustainable Development of Chinese Industry. Economic Research, No. 4, 41-55.

[13] Xi, J. (2013) Regional Dynamic Difference, Divergence and Variability of Carbon Emission Efficiency in China. Journal of Geographical Research and Development, 32, 83-87.

[14] Wu, X., Zhang, J., Tian, Y., et al. (2014) Study on Agricultural Carbon Emission in China's Provinces: Measurement, Efficiency and Influencing Factors-Based on DEA-Malmquist Index Decomposition and Tobit Model. Resource Science, 36, 129-138.

[15] Chen, S. (2011) China's Industrial Sector Statistics Estimates: 1980-2008. Economics, No. 2, 735-776.

[16] Zhang, J., Wu, G. and Zhang, J. (2004) China's Inter-Provincial Material Capital Stock Estimates: 1952-2000. Economic Research, No. 10, 35-44.

[17] Zhang, J. and Zhang, Y. (2003) Re-Estimation of China's Capital Stock K. Economic Research, No. 7, 35-43. 
Submit or recommend next manuscript to SCIRP and we will provide best service for you:

Accepting pre-submission inquiries through Email, Facebook, LinkedIn, Twitter, etc. A wide selection of journals (inclusive of 9 subjects, more than 200 journals)

Providing 24-hour high-quality service

User-friendly online submission system

Fair and swift peer-review system

Efficient typesetting and proofreading procedure

Display of the result of downloads and visits, as well as the number of cited articles Maximum dissemination of your research work

Submit your manuscript at: http://papersubmission.scirp.org/

Or contact lce@scirp.org 